\title{
21. \\ U IŠČEKIVANJU SMRTI \\ ILI PREPLITANJA ŽIVOTA I SMRTI \\ U REKONVALESCENTIMA \\ DRAGIŠE VASIĆA I BARACI 5 BE \\ MIROSLAVA KRLEŽE
}

\section{Iva Tešić}

UDK: 821.163.42-32Krleža, M.:821.163.41-32Vasić, D."192“"

Izvorni znanstveni članak

Sažetak: Rad je usredsređen na komparativnu analizu u čijem je fokusu otkrivanje međusobnih podudarnosti, odnosno razlika na tematsko-motivskom i ideološkom planu između Barake 5 be Miroslava Krleže i Rekonvalescenata Dragiše Vasića. Posebna pažnja posvećena je ratu kao književnoj temi, to jest ratnom kontekstu kao zajedničkom imenitelju ovim dvema proznim celinama. Drugu uporišnu tačku predstavljaju Frojdove teze o ratu i smrti, pre svega stav da rat menja čovekov doživljaj smrti, relativizujući odnos prema smislu postojanja, religiji, društvenim i životnim vrednostima. Dakle, u središtu interpretacije nalaze se misaone preokupacije junaka koji su u iščekivanju smrti. Pored toga, napravljen je i kratak osvrt na relaciju Miroslav Krleža - Dragiša Vasić.

Ključne reči: rat, smrt, bolnica, Dragiša Vasić, Miroslav Krleža

D a bismo se bavili uporednom analizom i osvetljavanjem međusobnih podudarnosti i razlika između Rekonvalescenata i Barake 5 be, potrebno je da uputimo na kontekst nastajanja pomenutih dela. Podsetimo, i Vasićeva i Krležina pripovetka deo su većih proznih celina - Rekonvalescenti su uvršćeni u Utuljena kandila, a Baraka 5 be u zbirku Hrvatski bog Mars. I jedna i druga pripovetka najpre su štampane u časopisima: Rekonvalescenti u Srpskom književnom glasniku 1922, da bi iste godine bili objavljeni kao integralni deo Utuljenih kandila, dok je Baraka 5 be prvo izašla u Novoj Evropi 1921. godine, a već naredne u knjizi Hrvatski bog Mars. Intertekstualnost pomenutih proza funkcioniše ne samo u relaciji sa drugim pripovetkama u zbirci, već i u okvirima posleratnog stvaralaštva.

Ratne okolnosti iznedrile su ekspresionističku umetnost - rat će u književnosti dvadesetih i tridesetih godina 20. veka postati dominantna tema. Čak i kada se eksplicitno ne 
govori o njemu, biće „prepoznatljiv po posledicama koje je ostavio u životu pojedinca“. Specifično je, možemo reći i tipično, pomeranje fokusa ka drami koja se zbiva u junacima, a ne na frontu. Naime, „i onda kada su opisivane neposredne situacije u toku rata, uglavnom su birane one koje su se dešavale u pozadini, za vreme zatišja, u bolnici (...) a ne na ratištu i u bitkama“. ${ }^{2}$ Skrenuli bismo pažnju i na činjenicu da je Prvi svetski rat sve do danas zadržao tzv. „literarnu auru“, kao i da je udeo književnosti u oblikovanju sećanja na period od 1914. do 1918. veći nego u bilo kom ranijem istorijskom trenutku. ${ }^{3}$ Kataklizma koja se dogodila stvorila je nepomirljive razlike između svega onoga što joj je prethodilo, i što je nastupilo po njenom okončanju. $\mathrm{O}$ jazu između predratne i posleratne literature možda najupečatljivije svedoči Miloš Crnjanski:

Deset miliona mrtvih i dvadeset miliona skrhanih telesa i preobraženih duša dele predratnu prošlost što se još jedva nazire, u godinama posleratnih promena, jednom zauvek, od sadašnjosti i budućnosti. ${ }^{4}$

Podsetićemo i na Objašnjenje „Sumatre“, u kojem Crnjanski ističe „nove osetljivosti“ koje su nastupile nakon rata:

Svud se danas oseća da su hiljade i hiljade prošle kraj lešina, ruševina, i obišle svet i vratile se doma, tražeći misli, zakone i život kakvi su bili. Tražeći staru, naviklu književnost, poznate, udobne senzacije, protumačene misli. (...) Ali su došle nove misli, novi zanosi, novi zakoni, novi morali! ${ }^{5}$

Rat i literarne junake i stvaraoce i tadašnje čitaoce objedinjuje u istovetnoj egzistencijalnoj situaciji. S tim u vezi iskrsava pitanje koliko, zapravo, u posleratnim ostvarenjima ima tragova lične istorije. Krleža je u članku Moja ratna lirika podvukao značaj činjenice da je njegova rana poezija bila obeležena atmosferom u kojoj je stvarana:

Sve je u toj lirici pogrebno, jer je sve oko nje i pod njom, kad je nastajala, bilo isto tako pogrebno. Rađajući se kao odraz stanja i prilika, ona nije mogla da bude odvojena od neprestanog razmišljanja nad otvorenim grobovima, i tako ni sama nije drugo nego neprekidno pokapanje, sprovod i smrt. ${ }^{6}$

Ratna trauma je u slučaju Dragiše Vasića isticana kao specifični spiritus movens. Kritičari su upravo iskustvu rata pridavali presudni značaj, čak tvrdeći da je ono od Vasića stvorilo pripovedača. Prvi je takvu ocenu izneo Slobodan Jovanović u predgovoru Utuljenim kandilima: „G. Vasića načinio je pripovedačem sam život. On je dobio u ratu suviše jake utiske, koji su ga suviše tresli i mučili; on je počeo pisati da bi se tiranije tih utisaka oslobodio. ${ }^{\text {"7 } ~ I ~}$

\footnotetext{
Radovan VučKović, Srpska avangardna proza, Beograd 2002., 36.

2 Marko Nedić, „Književno delo Dragiše Vasića u okvirima novije srpske književnosti“, Dragiša Vasić (prir. Marko Nedić), Novi Sad 2012., 17.

3 Dunja Dušanić, Fikcija kao svedočanstvo. Iskustvo Prvog svetskog rata u prozi srpskih modernista, Beograd $2017 ., 335$.

4 Gojko Tešić, Srpska književna avangarda. Književnoistorijski kontekst (1902-1934), Beograd 2009., 27.

5 Miloš Crnjanski, „Objašnjenje 'Sumatre'“, Itaka i komentari, Beograd 1959., 176-177.

6 Miroslav KrležA, „Moja ratna lirika“, Evropa danas. Knjiga dojmova i essaya, Zagreb 1935., 39.

7 Slobodan Jovanović, „Dragiša Vasić. Predgovor Utuljenim kandilima“, Crvene magle (prir. Gojko Tešić), Beograd 1990., 132.
} 
Milan Bogdanović je smatrao da Vasić „robuje teškim utiscima“ koji moraju biti izrečeni, zbog čega mu se čini osnovanim pitanje „da li će Dragiša Vasić od onog dana kada bude izrekao svoju moru od rata, koja mu pritiskuje duh i dušu, osećati potrebu da i dalje pišse. 8 Možemo dodati da je ovakva nedoumica, ispostavlja se, bila osnovana i da je Vasić tridesetih godina zaista prestao da piše. Možda se pisanjem privremeno oteo „užasu koji ga je upravo i podstakao da stvara"9 ili je posredi neko drugo objašnjenje, ali činjenica je da je na Krležin predlog da sarađuje u časopisu Danas odgovorio na sledeći način: „Kakvi bakrači, ne zanima me, brate, nikakva literatura!" ${ }^{10}$

Međutim, neposredno po završetku rata, Krleža i Vasić stvarali su, kao i ostali pripadnici posleratne generacije, $u$ atmosferi beznađa, defetizma i potpune dezorijentisanosti. Posleratni trenutak bio je neuporediv sa prethodnim iskustvima, jer „nikada ranije nijedan događaj nije razorio toliko opštih dobara (...) zbunio tako mnogo najsjajnijih umova, niti toliko unizio ono najviše “. ${ }^{11} \mathrm{U}$ takvom ambijentu Ničeova ideja o sumraku sveta i smrti boga nije samo puko teorijsko polazište - nihilistička vizija prestaje da bude isključivo proizvod filozofskog promišljanja, postajući ogledalo duhovnog stanja epohe, ali i „umetničko-literarni materijal za neprolazna dela“. ${ }^{12}$

Promena koju zapažamo u narativnim ostvarenjima iz posleratnog razdoblja ogleda se $\mathrm{u}$ činjenici da istorijska dešavanja postaju periferna, dok se interesovanje usmerava prema unutarnjem, psihološko-emotivnom. Umesto faktografiije dobijamo uvid u zbivanja s obzirom na trag koji ona ostavljaju u svesti junaka. Ključno, čini se i opsesivno pitanje koje iskrsava pred svim povratnicima, ali i svim preživelima, sročeno je u prvim redovima Dnevnika o Čarnojeviću Miloša Crnjanskog, i glasi: „Gde je život?“ Apsolutni slom vrednosti koji je čovečanstvo doživelo nakon Velikog rata donosi potrebu za pronalaženjem uporišta koje će obezbediti smisao i vratiti veru u život. Na literarnom planu doći će do stvaranja antiratne književnosti i ponovne aktualizacije priče o čoveku u ratu, ali iz potpuno novog ugla. Junaci čiji je život obeležen iskustvom rata uspostaviće paradigmu koja predstavlja antonim tradicionalnoj predstavi rata i odlaska u rat. Dok je u prošlosti sagledavan kao neka vrsta „svete dužnosti“, odnosno povoda da se istaknu vrline (junaštvo, patriotizam, požrtvovanost, odricanje...), u ovom periodu gubi se herojsko-mitska perspektiva i rat biva doživljen kao infernalni ambijent koji preti da satre i uništi.

I Frojd je smatrao da takav rat više „ne pruža priliku za postizanje starog ideala junaštva“. ${ }^{13}$ Međutim, upravo je kontekst Prvog svetskog rata za njega predstavljao svojevrsnu inspiraciju, koja će uticati na stvaranje teorije agresivnosti. „Poplava zla i stradanja“" ${ }^{\text {“4 }}$ poslužila je tvorcu psihoanalize kao potvrda pretpostavke da agresija nije stečeni niti naučeni oblik

\footnotetext{
Milan Bogdanović, „Dragiša Vasić Crvene magle“, Crvene magle, 217-218.

Isto, 217.

10 Stanko Lasıć, Krleža, kronologija života i rada, Zagreb 1982., 248.

11 Sigmund Frojd, „Aktuelna razmatranja o ratu i smrti“, Antropološki ogledi. Kultura, religija, umetnost (prir. Žarko Trebješanin), Beograd 2011., 121.

12 Milan Bogdanović, „Rat i literatura“, Politika (Beograd), br. 4164, 6. 1. 1919., 2.

13 S. Frojd, „Aktuelna razmatranja o ratu i smrti“, Antropološki ogledi, 118.

14 Ivo Andrić, „Naša književnost i rat“, Istorija i legenda. Eseji I (prir. Radovan Vučković), Beograd - Zagreb - Sarajevo - Ljubljana - Skoplje 1976., 176.
} 
ponašanja, već inherentni potencijal. Prema njegovom tvrđenju, ispoljavanje animalnih nagona zadovoljava čovekovu urođenu subverzivnost, koja u ratnim okolnostima biva pobuđena, dobijajući prostor za legitimizaciju. U vreme trajanja rata, tačnije 16. februara 1915, Frojd je članovima izraelskog humanitarnog udruženja B'nai B'rith održao predavanje Mi i smrt. ${ }^{15}$ U njemu je prvi put pomenuo nagon smrti. U kasnijim esejima Frojd će se podrobnije baviti odnosom između tanatosa i erosa - nagona smrti, nazvanog prema grčkom bogu Tanatosu, i njegovog oponenta Erosa, koji predstavlja ovaploćenje vitalističkog instinkta. ${ }^{16}$ Uvođenjem pojma „nagon smrti“ radikalno se raskida sa svim prethodnim diskursima na temu smrti, u kojima je smrt „ili otvoreno negirana i sublimirana, ili dijalektizovana“. ${ }^{17}$

Frojdov stav je da negativni impulsi koji potiču iz nagona smrti jesu značajna pogonska / motivaciona sila u čovekovom životu, a ratni prostor najpogodniji je za njihovo aktiviranje i manifestovanje. Prema Žanu Bodrijaru,

(...) pojavom Frojda, sa filozofskog pojma smrti kao drame svesti prelazi se na poimanje smrti kao nagonskog procesa upisanog u poretku nesvesnog - sa metafizike straha na metafiziku nagona. Baš kao da je smrt (...) konačno otkrila svoj status objektivne svrhovitosti: nagonsku energiju smrti ili princip psihološkog delovanja. ${ }^{18}$

Frojdovo ubeđenje je da svaka ljudska jedinka u nesvesnom gaji ideju o svojoj besmrtnosti i permanentno tokom života ignoriše činjenicu o sopstvenom kraju. Međutim, ratne okolnosti donose promenjenu percepciju smrti. U okvirima neprestanog i svakodnevnog masovnog umiranja čovek je onemogućen da svesno eliminiše, ukine misao o njenoj neminovnosti. Rat, zapravo, oličava pozornicu smrti, na kojoj je nužno suočavanje sa činjenicom da smrt prestaje da bude samo smrt drugog i postaje sveopšta izvesnost.

Preplitanja erosa i tanatosa na jednom omeđenom narativnom prostoru možemo pratiti u pripovetkama Baraka 5 be i Rekonvalescenti. I Vasić i Krleža biraju bolnicu za scenografi-

15 Sigmund Frojd, Mi i smrt. Našstav prema smrti: dosad neobjavljeni rukopisi i predavanja (prir. Žarko Martinović i Milica Martinović), Beograd 2001.

16 U pismu Ajnštajnu, pisanom 12 godina po okončanju rata a naslovljenom Zašto rat?, stav o dva nagona definisan je na sledeći način: „Pretpostavljam da postoje dve vrste ljudskih nagona: prvi koji teže održanju i ujedinjenju - nazivamo ih 'erotski', sasvim u skladu sa značenjem Erosa u Platonovoj Gozbi, ili 'seksualni', sa svesnim proširenjem popularnog pojma seksualnosti - i drugi koji teže razaranju i ubijanju: njih zajednički sažimamo pod imenom nagona za agresijom, ili razornog nagona.“ (S. FroJd, „Zašto rat?“, Antropološki ogledi, 114-115.) Odnos prema tanatosu kao „potomku i glavnom predstavniku smrti“ opisan je i u eseju Nelagodnost u kulturi (1930). Ovom prilikom Frojd je razmatrao udeo pomenutih nagona u razvoju kulture, pri čemu je erosu pripala ujediniteljska uloga, koja je u službi kulture, dok njegov oponent oličava destrukciju i sabotažu: „Stojim, dakle, na stanovištu da sklonost agresiji predstavlja osnovni, samostalni nagon u čoveka, i ponavljam, on predstavlja najveću prepreku kulturi." (S. FroJD, „Nelagodnost u kulturi“, Antropološki ogledi, 68.) U pismu Zašto rat? Frojd, međutim, ističe uzajamnost i nerazlučivost pomenutih instinkata, tvrdeći da je erosu neophodan tanatos ne bi li ostvario sopstvene porive: „Tako je nagon samoodržanja očito erotske prirode, ali upravo on mora da raspolaže agresivnošću kako bi ostvario svoju nameru“, odnosno: „I ljubavnom nagonu usmerenom na objekte, u podjednakoj meri je potreban dodatak nagona za ovladavanjem ako uopšte želi da se domogne svog objekta.“ (S. FrojD, „Zašto rat?“, Antropološki ogledi, 115.) Osim toga, u pomenutom pismu otkrićemo i Frojdovu tezu o „biološkoj osnovi rata“: „Konačno, rat izgleda sasvim u skladu s prirodom, ima biološku osnovu i praktično je skoro neizbežan.“ (Isto, 118.) Otuda i konstatacija da je ljude „lako oduševiti za rat“ jer „u njima deluje (...) neki nagon za mržnjom i uništavanjem“. (Isto, 114.) Možemo primetiti da se ova misao nadovezuje na tvrdnju izrečenu 1915: „U nama nema nikakve nagonske odbojnosti prema prolivanju krvi. Potomci smo beskrajnog niza ubica." (S. FrojD, Mi i smrt, 50.)

17 Žan Bodrijar, Simbolička razmena i smrt, Gornji Milanovac 1991., 167.

18 Isto, 166. 
ju koja na najbolji način reprezentuje samrtnost, kao i tragiku ratne traume - bolnica je taj „crni talog pomerenosti, najtragičnije skupljeno na jednom mestu“. ${ }^{19}$ Svojevrstan paradoks je da ova izolovana sredina oličava privremeno utočište i sklonište od sigurne smrti. Dok se Vasićevi rekonvalescenti zahvaljuju bogu jer nisu na ratištu, bolesnici malteškog špitala gaje iluziju o sopstvenoj privilegovanosti jer se rat odvija tamo negde daleko, a oni se vesele i gledaju kroz bodljikavu žicu „van u užas“:

(...) njima je, eto gle, ipak kako-tako dobro. Stoje tu, pod Crvenim križem, i neće ih nikamo ganjati, a ako dođe Rus, i opet će ih transportirati nekamo daleko, u ruske bolnice i logore, i tamo neće biti rata, i ostat će živi. ${ }^{20}$

Krležin špital je „blatni krvavi pakao“ u kome se ljudi pretvaraju u brojeve koji, u zavisnosti od stepena fizičke oštećenosti, bivaju otpremljeni među polomljene kosti, amputirane, ili idu u baraku 5 be, što će reći na jedno kratko putovanje od kupaonice ka mrtvačnici. Svet Krležine Barake 5 be užaren je do usijanja - sve trune i vene na 49 stepeni Celzijusa:

(...) sunce [je] formalno zdrobilo svojom ognjenom masom zemlju, i tako je izgledalo kao da je netko na drvene bijele barake bacio gorući mlinski kamen da se sve zapalilo. Savijale se daske i pucale od suše (...) sve je to venulo, trulo, gnjilo i zgaženo; odnosno: Usijalo je sunce prokleto sve mozgove. ${ }^{21}$

U ekspresionističkom duhu, sa naturalističkim opisima, atmosfera špitala postaje groteskni ambijent $\mathrm{u}$ kome nagon za životom pacijente pretvara u maske koje u tom predsmrtnom beznađu mahnitaju:

Pjeva se, pije, razlijeva se rakija, pa se svrabljivci počeli da ganjaju metlama kroz barake, i viču, i sve reži kao menažerija, i tako izgleda da će se sve te barake, kao ranjene musave kokoši ćorave, skupiti pa početi poskakivati na jednoj odrezanoj i povezanoj nozi tamo-amo, po taktu topovske glazbe. ${ }^{22}$

Karnevalizovana atmosfera, razularenost i raspojasanost, naglašena seksualnost, koja se završava silovanjem bolničarki, protivteža su jedinom donekle individualizovanom liku, umirućem studentu Vidoviću, koji zapomaže u bolovima i moli za tišinu, dok na njegovoj postelji pijani Mađari igraju ajnc:

- Braćo draga! Molim vas! Mir! Mene boli! Mene strašno boli, viče Vidović, ali glas mu se gubi, i on samo hropti, i krv mu navire na zube. ${ }^{23}$

U toj masi jedino je on svestan skore smrti, i nemoćno razmišlja o sramotnoj situaciji u kojoj se nalazi. Njega na samrtnom času nema ko da čuje niti da mu pritekne u pomoć, zbog čega iz besa i očaja, revoltiran beznadežnošću, poželi da kao trag o svom postojanju ostavi crvenu krvavu mrlju. Na kraju život završava u lokvi sopstvene krvi.

19 Mihajlo Pantić, Modernističko pripovedanje - srpska i hrvatska pripovetka / novela 1918-1930, Beograd 1999., 235.

20 Miroslav KreežA, „Baraka 5 be“, Hrvatski bog Mars, Zagreb 2001., 235.

21 Isto, 231, 236.

22 Isto, 239.

23 Isto, 240. 


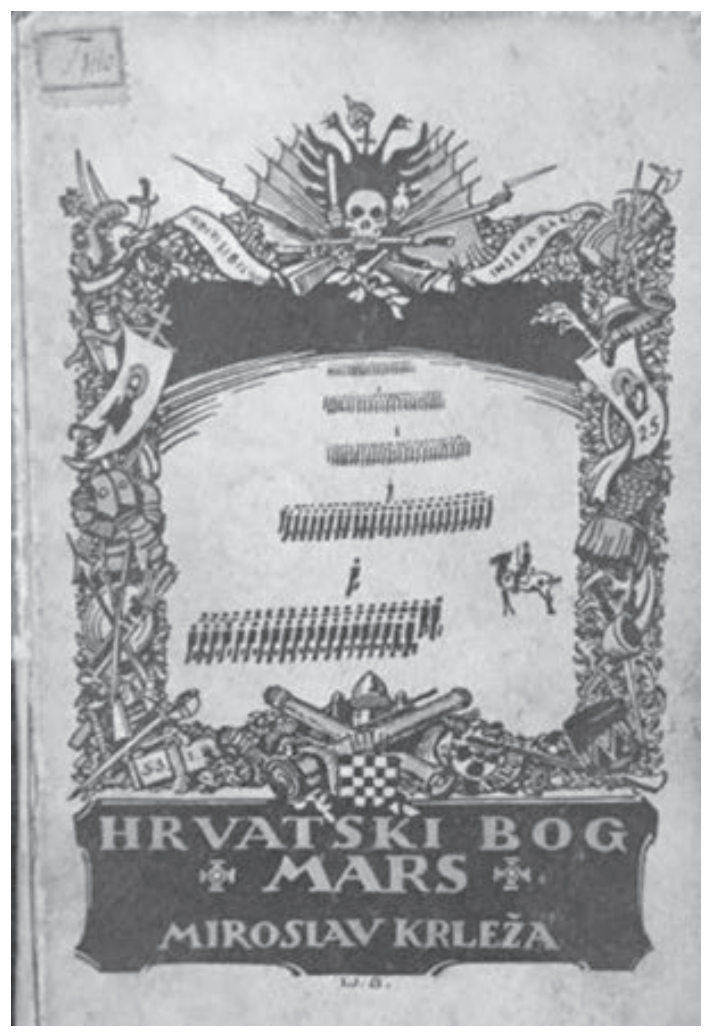

Sl. 1. Korice prvog izdanja zbirke Hrvatski bog Mars s ilustracijom Ljube Babića
I dok je u Baraci 5 be sve na ivici propasti, u perverziji i prepuštanju nagonima koji oslobađaju od svesti o skorom kraju, atmosfera u Rekonvalescentima nije kipuća niti prenaglašena - što je, uostalom, u skladu s Krležinim zapažanjem da je Vasić „miran naturalista kome violentne snage podsvesnih poriva ne previru preko solidne granice“. ${ }^{24}$ Vasićeva posmrtna postavka udavljena je maglom, u glibu, kiši i sivilu. Dekorisanost Krležine i Vasićeve samrtničke scenografije i „meteorološka motivisanost" umnogome se razlikuju, mada je prepoznatljiva simbolika kojom se dva pisca služe. Vatra, plamen i sunce važni su Krležini simboli - pomenimo da je Plamen i naslov časopisa čiji je bio osnivač i urednik, zatim da u čuvenom programskom tekstu Hrvatska književna laž zaziva plamen da spali laž hrvatske književnosti, a u Hrvatskoj rapsodiji, epilogu zbirke Hrvatski bog Mars, genije spasitelj vodi narod ka suncu. Nasuprot užarenoj Krležinoj simbolici stoji magla kao prepoznatljiv simbol Vasićeve ratne proze. Magla je prisutna i u naslovu Vasićeva ratnog romana Crvene magle, čak su i duševna stanja Vasićevih junaka obeležena magnovenjem: „Magla je stanište utvara i fatamorgana misli, a njena nesigurnost ne poništava samo 'pravi' smisao misli, već ga preinačava, patvori i premešta." ${ }^{25}$ Kao što Krležin plamen treba da pročisti svet, tako i Vasićeva voda priziva simboličko pranje, čišćenje. U Rekonvalescentima je uprizoreni svet rastočen - kiša koja danima pada kao da predskazuje potop:

I danima tako sipi, rominja, kisne, pa mokro sve, i teško, i uvijeno gustom kišnom maglom (...) sedam crnih paviljona sve više tone u glibu. Raskaljale se stazice (...) svuda žitko blato (...) zidovi mokri i stabla velikog drveća pokisla do srži (...) prokišnjavaju paviljoni i duša podrhtava od vlage i studeni. A dole, u ravni davi se varoš u potopu magle. ${ }^{26}$

U sivom, hladnom, kišnom i maglovitom prostoru, deleći zajedničko osećanje nervoze i bezizlaza, rekonvalescenti su okupljeni u grupice i vreme prekraćuju razgovorima. Možemo zapaziti da je u skoro svakoj priči koju bolesnici otpočinju (izuzev one posvećene pitanju vredi li umreti za otadžbinu) prisutna čežnja za ženom: jedan se pita da li ga žena vara, drugi pokazuje

\footnotetext{
24 Miroslav KrležA, „Dragiša Vasić“, Književna republika, 1/1923., br. 1, 97.

25 Milo Lompar, Moderna vremena u prozi Dragiše Vasića, Beograd 1996., 13.

26 Dragiša VAsıć, „Rekonvalescenti“, Sabrane pripovetke (prir. Gojko Tešić), Beograd 1990., 84.
} 
ženinu sliku i seća se bračnog života, treći tvrdi kako bi pristao da ga raznesu granate samo da može da provede noć sa ženom: „Pristao bih da me raznese granata najvećeg kalibra, samo da (...) je vidim kako mi prilazi... "27 Ipak, najupečatljivija je ispovest rekonvalescenta „smrtno zaljubljenog“ u Grkinju, suprugu „slavnog jednog zubnog lekara“ sa Krfa, koji priznaje:

Dok sam bio na tom divnom ostrvu, povadio mi je sve zube donje vilice; sad sam tražio bolovanje da tamo ostavim i sve zube svoje gornje vilice (hvala Bogu što čovek ima dve vilice!), a ja sam advokat, i moji zubi to su moji kapitali. Eto tolika je moja ljubav za Grkinje. Nagradu ne tražim. ${ }^{28}$

Čak se i imagološka sekvenca o Nemcima, Grcima i Francuzima završava rečima: „a rat, u krajnjem zaključku, to je seoba žena, to je razmena žena“. ${ }^{29}$

Dok je kod Krleže sve izobličeno, na ivici ponora i u preovlađujućoj vlasti tanatosa, kod Vasića se kao protivteža bezumlju javlja eros, onaj vitalistički princip čiji su nosioci žene. U bolesničkom prostoru njegove pripovetke trudna bolničarka figurira kao čisto otelovljenje erosa, kao simbol produžetka života, odnosno nosilac novog života:

Mala vižljasta, anđeoska miss Pound, sa zlatnim kovrdžicama na vratu i zaobljenim svojim trbuhom u kome nov život jedan sprema se. (...) nov život koji će doći ispuniće njen sav od slatkih uspomena na neobičnu ljubav u ovom crnom paviljonu, u kome je ona bila srećna kad su svi drugi patili, gde je ona raj svoj pronašla u ponoru najstrašnijeg pakla. ${ }^{30}$

Uprkos lišenosti smisla, u Vasićevoj pripoveci izostaje neobuzdanost mračnih sila koje vitlaju čovekom. Štaviše, rekonvalescenti opštem beznađu prkose šalom. Humor se pojavljuje kao vrsta odbrambene strategije koja poseduje oslobađajući efekat, pa kao lajtmotiv pripovetke iskrsava pitanje jednog potpukovnika: ima li žaba rep, odnosno zašto žaba nema rep, uz prateću sugestiju da treba misliti o onim stvarima. Nasuprot takvome humoru, junaci Barake 5 be zabavljaju se prognoziranjem smrti, tačnije - klade se na tuđe glave i zajedno nagađaju ko je sledeći kandidat smrti. Sakati, odnosno pripadnici grupe amputiranih, koji su ostali bez ruku ili nogu, trujumfuju jer su ipak živi: „Nemam ruke! Da! I kost mi je polomljena! Da! Ali živim! Gospode Bože! Još uvijek živim!“31

I dok među pacijentima špitala neosetljivost na tuđe stradanje ne samo što prestaje da uznemirava, već postaje izvor razonode, Vasićeva priča završava se tugom i plakanjem izvesnog kapetana koji je dobio vest da mu je žena umrla. Mada saznanje o ženinoj smrti u prvi mah prati razdragani osmeh zbog činjenice da se život, uprkos svemu, nastavlja („Samo kad sam živ, sve ću drugo lako“32), prvobitna misao preobraća se u želju da se rat nastavi jer povratak u svakodnevni život donosi, zapravo, suočavanje sa sopstvenom smrću: „Umrla mi je žena. (...) Jedna je žena umrla. Ah, ali ta žena što je umrla, to je moja žena, jedan ogroman deo mene je u njoj, to sam donekle ja umro. “33 Smrt voljenog bića na izve-

\footnotetext{
Isto, 94.

28 Isto, 112.

29 Isto, 112.

30 Isto, 113.

31 M. KrležA, „Baraka 5 be“, 233.

32 D. VAsIĆ, „Rekonvalescenti“, 115.

33 Isto, 116.
} 
stan način predstavlja delimičnu smrt nas samih - „Ti voljeni su, s jedne strane, unutrašnji posed, sastojci našeg sopstvenog ega. ${ }^{\text {“34 }}$

Istakli bismo da je ovo jedina smrt u Rekonvalescentima. Tačnije, reč je o reakciji na primljen telegram, nije u pitanju smrt koja se dogodila u bolničkom ambijentu. Nasuprot tome, malteški špital pravi je mali dance macabre, „perverzna lađa krcata ljudskim mesom“, u kojoj se istovremeno umire i slavi radost postojanja, mesto na kome pesma i muzika zaglušuju zapomaganja umirućih. Kod Krleže je upečatljiva, bolje reći zapanjujuća, neosetljivost na tuđa stradanja. Smrt je postala do te mere uobičajena da prestaje da uznemirava, na nju se više niko ne obazire:

Vani u sjenici (...) zvonile su čaše, a tu je broj devet u agoniji istrgao kanilu i potekla je krv. (...) Vidović je htio da viče, ali nije mogao do glasa. (...)

- Svijeću bi trebalo zapaliti! Za pokoj duše bi mu bilo! - Samo to je ponavljao neprestano, a oči su mu se prikovale o lokvu crvene krvi broja devet. I iza sve snage je hteo da zaurla, ali to je u njemu pištalo kao u rešetu. ${ }^{35}$

Svakodnevna umiranja u barakama na zaleđini fronta u potpunoj su opoziciji sa umiranjem kakvo je zamišljao šef špitala, grof Maksimilijan Akselrode:

Grof Maksimilijan Axelrode imao je za cijeloga svoga života samo jednu ideju da za svoju visoku maltešku devizu - Pro fide - povuče goli mač, da se zaogrne svojom crnom pelerinom što pada u teškim naborima, i da sune u smrt, vedra i smiona čela. ${ }^{36}$

Ipak, nesreća je učinila da je „pao ovamo na globus u kukavno i glupo doba“ i da se pod njegovom nadležnošću nađe „hiljadu i pol pacijentskih lubanja“, „lica natečena i krvava“ što su kao „crne sjene što trče tamo-amo u magli“, ne srljajući u „dostojanstvenu“ smrt za veru, već umirući u mukama. On je sanjao „idealnu smrt“, a zatekla ga je surova ratna stvarnost. Protivteža iluzijama o tome kako bi bilo „lepo“ umreti kosi se sa stvarnim umiranjima. Evo kako to izgleda iz ugla već „otpisanog“ studenta Vidovića, na koga su se kladili da neće doživeti jutro:

Čemu sam se ja zapravo rodio, i koju je svrhu to imalo? (...) Kako je sramotna moja smrt! Kako je duboko sramotna! Ja sam htio da doživim i da poživim! A šta se dogodilo? Śpitali i sami špitali! (...) Ovakve prljave, smrdljive, ušljive drvene barake! Ah, kako je sve to žalosno i gadno! ${ }^{37}$

Što je smrt bliža, snažniji postaju glasovi koji na raznim jezicima dozivaju Svevišnjeg. Svako ima nekog svog boga, „poslednju instancu“ koju priziva u pomoć. U graničnim situacijama iskrsava potreba za duhovnim, odnosno utešiteljskim konceptom koji će zanemariti činjenicu o telesnoj ništavnosti. Kod Krleže je prenaglašeno ludilo iščašene stvarnosti i stanovnici špitala utehu traže od „više sile“.

\footnotetext{
4 S. Frojd, „Aktuelna razmatranja o ratu i smrti“, Antropološki ogledi, 143.

5 M. KrležA, „Baraka 5 be“, 246.

36 Isto, 229.

37 Isto, 242.
} 
Bolnički prostor u Vasićevoj pripoveci obeležen je izrazitom nervozom, mada njegovi privremeni žitelji nisu izobličene i pomahnitale maske, već neurotičari koji boluju od najtipičnijeg signala „decentriranog subjekta, koji u ratu (...) sa bliskim iskustvom smrti, postaje svestan pukotina u sebi““.38 Uz sklerotičnog pukovnika, koji zavodi red među pacijentima, posebno je izdvojena grupica mladih oficira neurastenika, koji su

(...) povučeni, mirni i disciplinovani. Kad neko priča, oni se naginju, prave grčevite pokrete glavom kao da im je nešto tesno oko vrata, miču ramenima, mršte se, trepću, gledaju u nos ili ramena, ali ćute i slušaju. ${ }^{39}$

Vasićevi rekonvalescenti izvesnost smrti ne odagnavaju prepuštanjem destruktivnim porivima, već spasonosno rešenje pronalaze u pričanju, ili čak čitanju. Prema Andrićevim rečima, pričanje priča najstarija je i najdelotvornija metoda „zavaravanja krvnika“. Iako su te priče najvećim delom posvećene ženama, u njima ima mesta i za diskusiju na temu otadžbine, ratovanja i smisla umiranja za tuđe ideale:

Ja hoću da objasnim i ispitam onaj predački ostatak, ono osećanje što sam nasledio, ono mistično što u meni večno tinja, a protiv čega se racionalno večno buni. Ja hoću da znam: je l' me ta otadžbina istinski volela, je l' prema meni ispunila sve obaveze majke, pa da za nju padnem i žrtvujem se kao njeno dete? ${ }^{24}$

Ideološki prosede prisutan je i kod Krleže, ali ne u vidu rasprave. Apsurdnosti i izopačenosti do kojih dovode ideologije predočene su opisom sablasne povorke koja mimohodom i bakljadom treba da obeleži pobedu austrougarske vojske i pokloni se carskoj zastavi. „Da bi uspostavio autoritet carske zastave i discipline “, ${ }^{41}$ grof Akselrode naredio je da svi, bez izuzetaka, moraju tome prisustvovati, a sam je stajao na čelu kolone, predvodeći „sakate, šepave, iznakažene, povezane, amputirane, na štakama, kolicima, nosiljkama“. ${ }^{42}$

Besmisao rata i umiranja iz patriotskih pobuda, zarad otadžbine ili „u ime Božije“, možda najbolje sumiraju sledeće reči:

Iz antičke istorije naučilo se da mase treba zastrašivati Bogom da bi one bile pokorne. (...) Mi svi ratujemo u ime njegovo jedni protivu drugih. (...) Ali ja moram da kažem kako mi je onaj što ga ja nazivam dušmaninom (...) koji pati kao i ja i koga sam poslan da ubijem, miliji, bliži i draži uvek bio od (...) vajnoga brata moga, što je zdraviji od mene, a bogati se i blaguje (...) dok ja ispaštam. ${ }^{43}$

Vasićev junak, koji izgovara navedene reči, naglašava kako je patriotizam imao smisla jedino u staroj Grčkoj, gde je gubitak otadžbine značio ujedno i gubitak boga, što je podrazumevalo i nestajanje razloga da se živi. Patriotizam je postao prazno osećanje, otadžbina prazna reč, a svaka je „ideja o nacionalnom načelu prouzrokovala novu podvojenost među

\footnotetext{
M. Pantić, Modernističko pripovedanje, 217-218.

D. VAsić, „Rekonvalescenti“, 91.

40 Isto, 98.

41 M. KRLEŽA, „Baraka 5 be“, 241.

42 Isto.

43 D. Vasić, „Rekonvalescenti“, 102-103.
} 
ljudima i nove krvave raspre, koje bi svako drugo stanje stvari teško moglo izazvati“, ${ }^{44}$ što je stvaralo ponovne sukobe i povode za ratovanje.

Izneseni stav je zapravo „simptom opšte zgađenosti nad ratom u posleratnoj evropskoj literaturi““ ${ }^{45}$ Međutim, Frojdovo razmišljanje o pomenutoj temi podsetiće nas na „narcizam malih razlika" kao specifičan agens koji će u svim vremenima biti pretnja i izvor potencijalnih sukoba, odnosno ratova. Taj narcizam pohranjivaće agresivne porive i davaće uvek povoda da se negativni naboji usmere prema onome za koga smatramo da je po nekom svojstvu različit od nas. $S$ tim u vezi je i Frojdov zaključak da je rat biološki determinisan, ali i da su ratovi i suočavanje sa smrću sastavni deo egzistencije, to jest, nemoguće je ukinuti ih. Iz toga razloga, na završetku teksta o smrti, pisanog 1915. godine, predložiće da se latinska poslovica „Ako želiš sačuvati mir, budi spreman za rat“ preinači u: „Ako hoćeš da podneseš život, budi spreman da prihvatiš smrt“. ${ }^{46}$

Na samom kraju istakli bismo još jedan detalj. Osim mogućnosti za uspostavljanje književnih paralela, mogli bismo ukazati i na još jednu, neknjiževnu činjenicu. Stvaralaštvo Dragiše Vasića i Miroslava Krleže često je mereno ideološkim parametrima, što je dovelo do toga da ideološko-politički diskurs postaje neizostavan u tumačenju njihovog stvaralaštva. Iako nisu usamljeni slučajevi oni kojima je ideološka (ne)podobnost odredila, bar donekle, literarnu sudbinu i status u okvirima nacionalnih književnosti, ovu pojedinost naglašavamo kao još jednu podudarnost. Doduše, postoji i velika razlika. Krležino književno delo bilo je „igrom povijesnih vihora zabranjeno i prognano u tišine privatnih biblioteka“ ${ }^{47} \mathrm{i}$ taj progon trajao je od početka Drugog svetskog rata sve do Kongresa književnika održanog u Zagrebu 1949. Nasilno odstranjivanje umetnika kao pretnje političkom sistemu bila je neretka praksa. Međutim, eliminisanje Dragiše Vasića trajalo je neuporedivo duže. Mada se tridesetih godina Vasić zaista povukao iz književnih tokova, što je praćeno i radikalnom promenom dotadašnjih ideoloških polazišta, jedan intervju iz 1934. godine navodi nas na zaključak da je, ipak, imao i - čini nam se - želeo još toga da kaže. Da bi bilo jasnije, citiraćemo odgovor na pitanje da li će, nakon svega, nastaviti da se bavi pisanjem:

$\mathrm{Ne}$, sad je teško vratiti se na to. Tu je (...) i cela tragedija mog života. Prvo sam želeo da uđem u arenu političkog života. Sprečili su me. Posle sam morao da otvorim advokatsku kancelariju, mesto da se bavim književnošću. Morao sam se potpuno predati ovome poslu. Iz kancelarije ne mogu nikud. Prođe i po godinu dana a da mi ne dođe dan kad bih mogao pisati. U ovoj advokatskoj kancelariji prošlo je preda mnom do 2000 romana i priča. Utisci ostaju, ali na papir ne dolazi ništa. ${ }^{48}$

\footnotetext{
44 Isto, 101.

45 M. Lompar, Moderna vremena u prozi Dragiše Vasića, 143.

46 S. Frojd, Mi i smrt, 56.

47 Miroslav Vaupotić, Siva boja smrti, Zagreb 1974., 7.

48 Dragiša VAsıć, Dva meseca u jugoslovenskom Sibiru. Utisci iz Rusije / Putopisi / Eseji / Kritike / Članci (prir. Gojko Tešić), Beograd 1990., 353.
} 
Krleža je, međutim, nakon prinudne skrajnutosti nastavio nesmetano da radi, i njegove „priče“ nisu ostale neispričane. Štaviše, do smrti je bio vrlo cenjena i moćna figura u kulturoj javnosti Hrvatske. Za razliku od Krležinog prećutkivanja, koje je trajalo nekoliko godina, Vasićevo se proteže na nekoliko decenija - tek 1990. „došla su nam, trudom Gojka Tešića, Izabrana dela Dragiše Vasića“. ${ }^{49}$ Ipak, uprkos svemu, Krležina prognoza na kraju se obistinila: još 1923. godine, u Književnoj republici, najavljujući Vasića kao budućeg saradnika časopisa, Krleža izjavljuje da je ovaj nedovoljno poznati pisac

(...) zarezao crte svoga književnoga profila sigurno i markantno; te crte stajat će jasno kada svima šarlatanima i snobovima i piskaralima, što drljaju danas po poslednjoj fasoni sedmorazrednih listova već davno neće biti ni traga ni glasa. ${ }^{50}$

Od nekada vrlo bliskog prijatelja Vasić će, za Krležu, usled sticaja političkih okolnosti, postati „čovek na tragičnoj stranputici“. Njegova ideološka zastranjivanja dovešće do trajnog prekida svake, čak i poslovne, komunikacije dva književnika. Dragiša Vasić izgubiće život na stratištu, kao pripadnik ravnogorskog pokreta, i njegova smrt ostaće pod velom tajni, postajući predmet različitih mistifikacija jer ne postoje podaci gde, kada i kako je skončao.

Dakle, priča o smrti ne podrazumeva isključivo odnos prema fizičkom nestajanju. $\mathrm{Na}$ simboličkoj ravni možemo govoriti o različitim vidovima smrti. S tim u vezi, relacija Vasić - Krleža dopušta mogućnost bavljenja i fenomenom smrti jednog prijateljstva, ali i nekada zajedničkih ideoloških stremljenja, otvarajući time mogućnost za pokretanje i drugih mogućih pitanja o odnosu pomenutih autora.

\section{$\cos$}

\section{Literatura}

Ivo Andrić, „Naša književnost i rat“, Istorija i legenda. Eseji I (prir. Radovan Vučković), Beograd - Zagreb - Sarajevo - Ljubljana - Skoplje 1976., 169-174.

Žan Bodrijar, Simbolička razmena i smrt, Gornji Milanovac 1991.

Milan Bogdanović, „Dragiša Vasić Crvene magle“, Crvene magle (prir. Gojko Tešić), Beograd 1990., 217-224.

Milan Bogdanović, „Rat i literatura“, Politika (Beograd), br. 4164, 6. 1. 1919., 2.

Miloš Crnjanski, „Objašnjenje 'Sumatre'“, Itaka i komentari, Beograd 1959., 175-182.

Dunja Dušanić, Fikcija kao svedočanstvo. Iskustvo Prvog svetskog rata u prozi srpskih modernista, Beograd 2017.

Sigmund Frojd, Antropološki ogledi. Kultura, religija, umetnost (prir. Žarko Trebješanin), Beograd 2011.

Sigmund Frojd, Mi i smrt. Naš stav prema smrti: dosad neobjavljeni rukopisi i predavanja (prir. Žarko Martinović i Milica Martinović), Beograd 2001.

49 M. Pantić, Modernističko pripovedanje, 210.

50 M. KrležA, „Dragiša Vasić“, 97. 
Slobodan Jovanović, „Dragiša Vasić. Predgovor Utuljenim kandilima“, Crvene magle (prir. Gojko Tešić), Beograd 1990., 127-135.

Miroslav KrLEŽA, „Baraka 5 be“, Hrvatski bog Mars, Zagreb 2001., 227-247.

Miroslav KrležA, „Dragiša Vasić“, Književna republika, 1/1923., br. 1, 97.

Miroslav KrležA, „Moja ratna lirika“, Europa danas. Knjiga dojmova i essaya, Zagreb 1935., 33-43.

Stanko LAsıć, Krleža, kronologija života i rada, Zagreb 1982.

Milo Lompar, Moderna vremena u prozi Dragiše Vasića, Beograd 1996.

Marko Nedić, „Književno delo Dragiše Vasića u okvirima novije srpske književnosti“, Dragiša Vasić (prir. Marko Nedić), Novi Sad 2012., 7-25.

Mihajlo PAntić, Modernističko pripovedanje - srpska i hrvatska pripovetka / novela 1918-1930, Beograd 1999.

Gojko TEšić, Srpska književna avangarda. Književnoistorijski kontekst (1902-1934), Beograd 2009.

Dragiša VAsıĆ, Dva meseca u jugoslovenskom Sibiru. Utisci iz Rusije. Putopisi / Eseji / Članci (prir. Gojko Tešić), Beograd 1990.

Dragiša VAsıć, „Rekonvalescenti“, Sabrane pripovetke (prir. Gojko Tešić), Beograd 1990., 84-121. Miroslav VAupotić, Siva boja smrti, Zagreb 1974.

Radovan VučKović, Srpska avangardna proza, Beograd 2002.

\section{$\cos$}

\section{WAITING FOR DEATH, OR THE INTERTWINING OF LIFE AND DEATH IN DRAGIŠA VASIĆ'S REKONVALESCENTI AND Miroslav KrležA's BARAKA 5 BE}

The paper provides a comparative analysis of the similarities and differences between Miroslav Krleža's Baraka 5 be (Barracks 5b) and Dragiša Vasić's Rekonvalescenti (The Reconvalescents) on the ideological and theme-motif levels. War as a literary theme is given particular attention, particularly, the wartime context as a common denominator between these two pieces of prose. Freud's theses on war and death are a second point of reference, above all the opinion that war changes the attitudes towards death and relativises the perspectives on the meaning of life, religion, social and other values. At the center of the analysis are the preoccupations of the protagonists who are waiting for death. Additionally, insights are provided into the relationship between Miroslav Krleža and Dragiša Vasić, allowing us to address the phenomenon of their friendship, as well as their often shared ideological strivings, while opening the possibility of raising more potential questions concerning those two authors.

Key words: war, death, hospital, Dragiša Vasić, Miroslav Krleža 